\title{
機械的荷重補償装置の開発*
}

\section{Development of Weight Switching Mechanical Gravity Canceller} \\ Yasuyuki YAMADA*1, Suguru NAGASAKA and Toshio MORITA \\ ${ }^{* 1}$ Keio University. Graduate School of Science and Technology \\ 3-14-1 Hiyoshi, Kohoku-ku, Yokohama-shi, Kanagawa, 223-8522 Japan
}

山田 泰之*1, 長坂 俊*2, 森田 寿郎 ${ }^{* 3}$

In this paper, we propose a passive gravity compensation mechanism for carrying load with two springs and switching mechanism, which named "Weight Switching Mechanical Gravity Canceller (WS-MGC)." The WS-MGC has following advantages with the original MGC in load compensation. The original MGC required to determine the compensation weight from the beginning and to make actuator bear the load when end-effector has new luggage and carries it. In this case, it is effective to switching the compensation weight from the weight of the machine to the total weight of both machine and luggage, without power supply. WS-MGC can switch the compensation weight by the weight of luggage. From development and experiments of a link model equipped with WS-MGC, it is clarified that the versatile device is succeed to step up from weight compensation to load compensation.

Key Words : Switching Mechanism, Load Compensation, Material Handling Equipment, Balancing, Gear

\section{1. 緒言}

現在, 様々な目的で機械的な自重補償機構が研究されている(1) (10). これらは，ポテンシャル要素を利用して， 垂直型多連結シリアルリンク形式のマニピュレータにおける関節ごとの自重トルクを相殺することで，アクチュ エータの出力を目的の作業に効率的に使用寸ることを狙った機構である. 最も有名な方式はカウンタ・ウエイト方 式であるが, 単純なカウンタ・ウエイト方式では, 多連結された場合の先端リンクへと駆動力を伝達できない. 広瀬らは，カウンタ・ウエイトのポテンシャルとアクチュエータの駆動力をワイヤとプーリで伝達する方法で多 連結シリアルリンク機構の自重補償と駆動の両立に成功している(2)(4)(6).

一方で，カウンタ・ウエイトによる自重補償では，装置自重や慣性を大きく増加させてしまうため，ポテンシ ヤル要素としてばねを利用寸る自重補償機構が考案されている，中でも，森田らは引っ張りばね，プーリとワイ ヤを用いて，3 次元空間でのマニピュレータの自重補償に成功している(3)(5). しかし，これらの機械的な自重補償 装置は作動リンクの自重を補償するにとどまっており, 補償荷重を初期に設定するのが一般的である.そのため, 作動リンク先端のエンドエフェクタが荷を把持して, 続けて運搬を行う場合などにおいて, 作動リンクの関節保 持トルクは把持した荷の自重分だけ増加してしまい，自重補償装置の効果が大きく薄れてしまう。つまり，自重 補償装置が取り付けられていても，荷の自重が増加した分をアクチュエータが負担しなければならない。このよ うな場合，荷の把持と同時に作動リンクの補償量の設定値を，作動リンクと把持した荷の合計重量に自動的に切 替えられれば，荷を運搬する作業においても常にマニピュレータはアクチュエータの出力を効率的に使用できる と考えられる.

本研究では，機械的自重補償装置(MGC：Mechanical Gravity Canceller $)^{(3)(5)}($ 図 1，2，付録参照)の補償原理に注目

\footnotetext{
* 原稿受付 2011 年 2 月 25 日

*1 学生員, 慶應義塾大学大学院総合デザイン工学専攻（†223-8522 神奈川県横浜市港北区日吉 3-14-1）

*2 慶應義塾大学大学院開放環境専攻

*3 正員, 慶應義塾大学理工学部

E-mail: 156@z6.keio.jp
} 


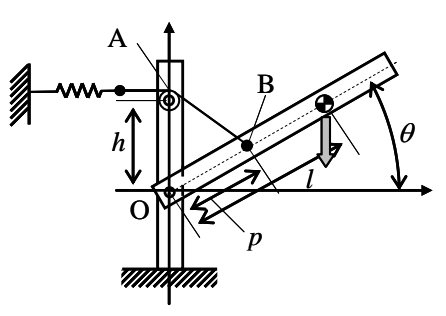

Fig. 1 MGC (Type-1)

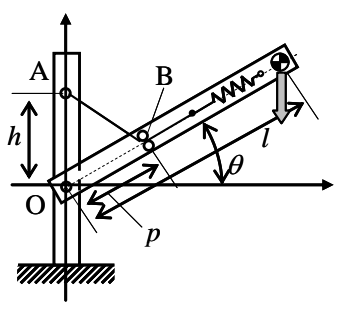

Fig. 2 MGC (Type-2)

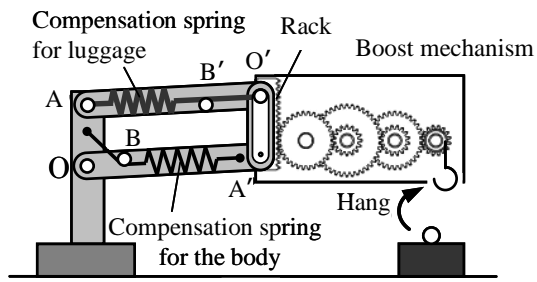

(a) Without luggage

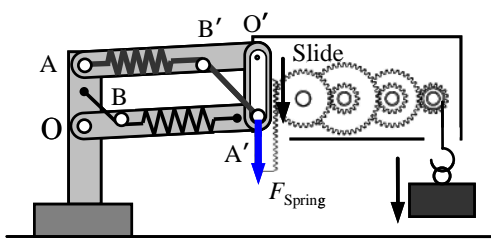

(b) With luggage
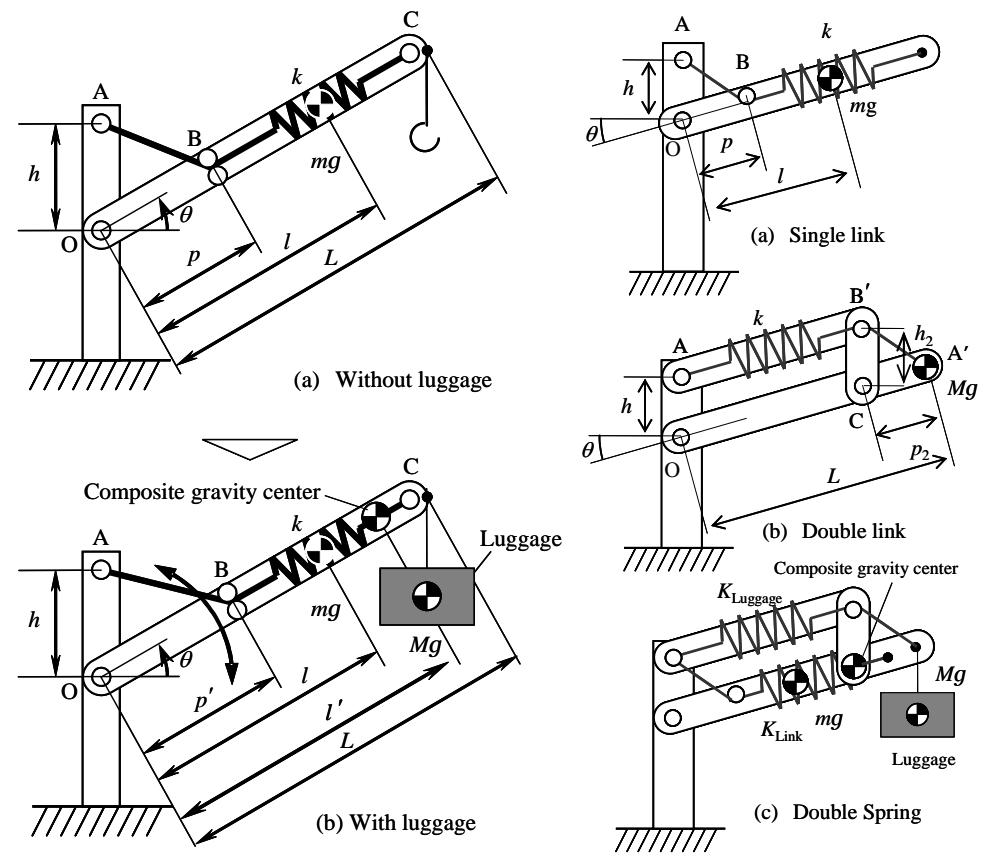

Fig.3 Mechanism of WS-MGC

Fig. 4 Single-link switching mechanism

Fig. 5 Variations of spring arrangement

して，機械的な荷重補償装置の実現を試みた。まず，作動リンクの自重補償と，荷の荷重補償をそれぞれ別に設 けたばねで行う機構とした，さらに，独立させた荷の荷重補償用のばねにより発生する補償力を，マニピュレー タが把持する荷の荷重のみで ON/OFF 可能とする倍力装置を取り付けた．結果，作動リンク自重のみを補償する 状態と後に把持した荷の荷重も合わせて補償する状態を簡単に切替えることができる, 機械的荷重補償装置 (WS-MGC : Weight Switching-MGC)を実現した.

\section{WS-MGC の提案}

\section{$2 \cdot 1$ WS-MGC の概要}

図 3 に機械的荷重補償装置(WS-MGC : Weight Switching-MGC)の概要を示寸. 図のように，作動リンクは平行 リンクを構成している.作動リンク自重の補償と,瞅架された荷の荷重はそれぞれ別のばねを用いて補償される.

荷重が変化した場合の補償量の切替えは，他の大きな外力なしに容易に切替が可能なように，懸架する荷の荷 重を用いることとした。これは，作動リンク先端のフックに荷を懸架した場合，フックに接続された倍力装置に より荷重補償用ばねの右端点が点 $\mathrm{O}^{\prime}$ から点 $\mathrm{A}^{\prime}$ ヘスライドして荷重補償用ばねが張られて(モーメントアームが 生成し), 荷重も補償できる状態（図 3(b)）に切替わる方法である. なお, 荷が懸架されていない場合, 荷重補償 用ばねは上部リンク $\mathrm{AO}^{\prime}$ に対して平行に張られており, 点 $\mathrm{O}^{\prime}$ まわりにモーメントが生じないので, 荷の荷重を 補償する補償トルクは発生しない(図 3(a))。 なお, WS-MGC は平行リンク機構を用いているため, 複数個を直列 に連結しても, 水平方向に可動する作動リンクを連結しても荷重補償が行える. そのため, 図 3 のような円弧運 動を行う補償装置だけでなく, 関節を増やせば垂直平面内の自在な位置での補償が実現可能である.

以下の節では WS - MGC のばね配置, 補償量の切替に必要な力の導出について説明し, 次章では補償荷重切替 機構の倍力方法と, ギア選択, 倍力装置のストッパ設計などの倍力装置について説明する. 


\section{$2 \cdot 2$ WS-MGC のばね配置}

荷重補償を行う場合，作動リンクの自重補償状態から荷の荷重補償分の増加を，(i) 作動リンクの自重補償に用 いているばねを利用して補償する形式と，(ii）別途に設けたばねで荷の荷重を補償する形式が想定される.

\section{（i） 1 本のばねを利用する形式}

荷を取り付ける前は，ばねは作動リンクの自重を補償している。このとき図 4 に示したように，作動リンクの 質量を $m$, 作動リンクの重心位置を $l, \mathrm{OA}$ 間距離を $h, \mathrm{OB}$ 間距離を $p$ とすると, 補償に必要なばね定数 $k$ は, 付録より以下のようになる.

$$
k=\frac{m g l}{h p}
$$

次に，荷を取り付けた後の補償に必要なばね定数 $k^{\prime}$ を考える. 荷の質量を $M$, 作動リンクと荷の質量の合成重 心位置を $l^{\prime}$, 荷を取り付けた際の $\mathrm{OA}$ 間距離を $h^{\prime}, \mathrm{OB}$ 間距離を $p^{\prime}$ とすると, ばね定数 $k^{\prime}$ は以下のようになる.

$$
k^{\prime}=\frac{(m+M) g l^{\prime}}{h^{\prime} p^{\prime}}
$$

荷の取り付け前後でばね定数を変化させることは機械設計上困難であるため，ばね定数は一定であるとした $\left(k=k^{\prime}\right)$. この場合, 式(1)におけるばね定数 $k$ と式(2)におけるばね定数 $k^{\prime}$ の比較で分かるように, 荷の取り付け前 後で $p^{\prime}, h^{\prime}, l^{\prime}$ のパラメータを調整する必要がある.ただし, 補償状態を保つためには, 調節の前後で作動リン ク角度を変更してはいけない，そのため，例えば， $p^{\prime}$ の大きさで調整を行う場合は，

$$
p^{\prime}=(m+M) p
$$

と OB 間距離を調整し，同時に作動リンク角度が変わらないようにワイヤ長さを変更する必要がある.

\section{（ii）別途に設けたばねを使用する形式}

作動リンクに補償用ばねを取り付ける方法としては，図 5(a)の方法や，図 5(b)のように平行リンクを介する方 法が存在する.今回は，図 5(c)のように，作動リンクの自重の補償を行うばねを(a)の方法で取り付け，荷の荷重 の補償を行うばねを(b)の方法で取り付ける. 作動リンク質量を $m$, 荷の質量を $M$ とすると, 荷を䀣架したときの 点 $\mathrm{O}$ まわりのトルク $\tau$ は, 作動リンクの質量と荷の質量の合成重心が, 点 $\mathrm{O}$ から作動リンクに沿って

$$
l^{\prime}=\frac{m l+M L}{m+M}
$$

の位置であることを利用して，

$$
\begin{aligned}
& \tau=-(m+M) g \frac{m l+M L}{m+M} \cos \theta \\
& =-(m g l \cos \theta+M g L \cos \theta)
\end{aligned}
$$

と表せる．式(5)の右辺第一項と第二項はそれぞれ，作動リンクの自重トルクの式(付録の式(A4))と同様の形で表 わされている，そのため，付録式(A5)と同様に MGC の補償原理に則り，式(5)の右辺の第一項と釣り合うように ばね定数 $K_{\text {Link }}$ の作動リンク補償用ばねを設定して，第二項と釣り合うようにばね定数 $K_{\text {Luggage }}$ の荷重補償用ばね を設定することで合成質量の自重補償が可能となる.

$$
K_{\text {Link }}=\frac{m g l}{h_{1} p_{1}}
$$




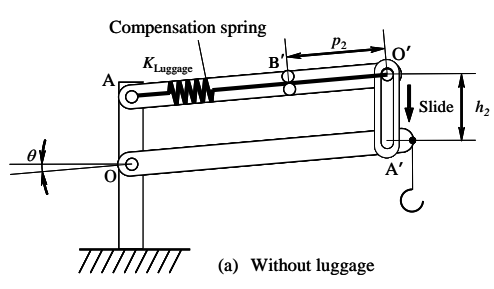

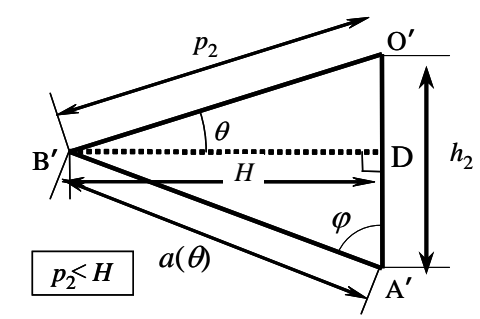

Fig. 7 Geometric relationship of boost mechanism
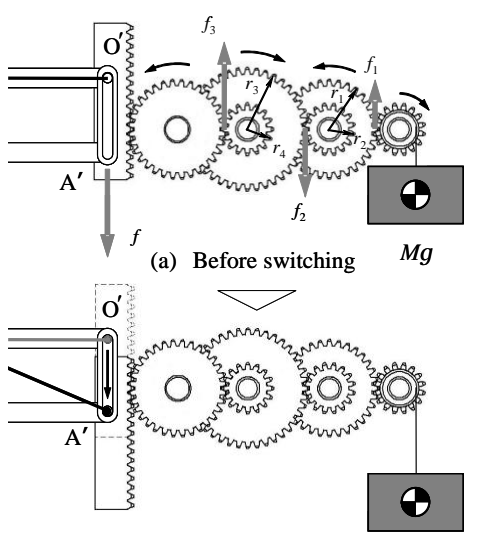

(b) After switching

Fig. 6 Double-link switching mechanism

$$
K_{\text {Luggage }}=\frac{M g L}{h_{2} p_{2}}
$$

このような荷を懸架したときの作動リンク全体のモーメントを, 作動リンク自重によるモーメントと荷重によるモーメントに 分解し，個々のばねで独立して補償する機構は 図 5(c)のような構造で容易に実現できる.この機構を用いれば，荷の 懸架の前後で, 荷の重量を補償するために別途に設けたばね(ばね定数 $\left.K_{\text {Luggage }}\right)$ を取り外した状態から取り付け た状態へと変更することで補償力を切替えることが出来る.

以上の二つの方法を比較すると，(i )の形式では， $p^{\prime}, h^{\prime}, l^{\prime}$ のパラメータ調整とワイヤ長さの調整を同時に行 う必要があるが，(ii )の形式は，別途に設けたばねを独立して変更すればよいだけなので，より簡単な構造で実 現できることから，これを採用した。

\section{$2 \cdot 3$ 切替力の算出}

荷の補償と非補償を切替るため, 図 6 のようにばねの端点をスライドできる機構を用いる．補償 OFF(図 6(a))

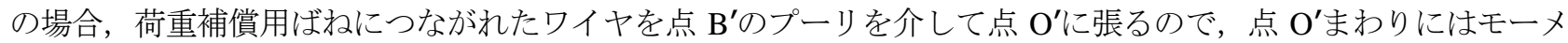
ントが働かない，一方，荷の重量を補償するときに，補償 ON(図 6(b))の状態にするためには，OFF の状態で荷を フックに懸架して，点 $\mathrm{O}^{\prime}$ にあったワイヤの右端点を点 $\mathrm{A}^{\prime}$ とスライドさせる必要がある. この状態は図 5(b)に示 したワイヤの幾何学的な関係と同じであり，荷重補償状態が実現できる．この状態にするために必要な引張力 $F_{\mathrm{Spring}}$ は, 作動リンクの回転中心と荷重の重心位置の距離を $L$, 線分 $\mathrm{B}^{\prime} \mathrm{O}^{\prime}$ の長さを $p_{2}$, 線分 $\mathrm{O}^{\prime} \mathrm{A}^{\prime}$ の長さを $h_{2}$, ワ イヤが屈曲する転 $\mathrm{B}^{\prime} か ら$ 辺 $\mathrm{O}^{\prime} \mathrm{A}^{\prime}$ 上でスライドするワイヤ端点までの距離を $a(\theta)$ とすると,

$$
\begin{aligned}
F_{\text {Spring }} & =K_{\text {Luggage }} \times a(\theta) \cos \varphi=\frac{M g L}{h_{2} p_{2}} a(\theta) \cos \varphi \\
& =\frac{L a(\theta) \cos \varphi}{h_{2} p_{2}} M g
\end{aligned}
$$

と表せる。ここで点 $\mathrm{A}^{\prime} ， \mathrm{~B}^{\prime} ， \mathrm{O}^{\prime}$ からなる三角形(図 7)に注目すると，付録式(A2)と同様に，

$$
\begin{gathered}
H=p_{2} \cos \theta=a(\theta) \sin \varphi \quad \therefore \sin \varphi=\frac{p_{2}}{a(\theta)} \cos \theta \\
\cos \varphi=\sqrt{1-\left(\frac{p_{2}}{a(\theta)} \cos \theta\right)^{2}}
\end{gathered}
$$


の関係が成立する.さらに $a(\theta)$ 引゙角形 $\mathrm{A}^{\prime}, \mathrm{B}^{\prime}, \mathrm{O}^{\prime}$ の幾何学関係から, $\quad a(\theta)=\sqrt{h_{2}{ }^{2}+p_{2}{ }^{2}-2 h_{2} p_{2} \sin \theta}$ と表せるこ とに注目し，この式(9)を式(8)に代入すると，

$$
\begin{aligned}
& F_{\text {Spring }}=\frac{L \sqrt{a^{2}(\theta)-p_{2}{ }^{2} \cos ^{2} \theta}}{h_{2} p_{2}} M g=\frac{L \sqrt{h_{2}^{2}+p_{2}^{2}-2 h_{2} p_{2} \sin \theta}}{h_{2} p_{2}} M g \\
& =\frac{L\left(h_{2}-p_{2} \sin \theta\right)}{h_{2} p_{2}} M g\left(\because h_{2}>p_{2} \sin \theta\right)
\end{aligned}
$$

となる.この式(10)から, 荷重の $L\left(h_{2}-p_{2} \sin \theta\right) /\left(h_{2} p_{2}\right)$ 倍の倍力が補償量切替のために必要になることが分かる.

\section{3. 倍力装置}

\section{$3 \cdot 1$ 倍力装置の形式}

倍力装置の形式として, 倍力率を細かく設定できるように, 図 8 のようにラックとギアを用いる形式とした。 この装 置ではギアの回転はギアの半径の比率により倍力されて，ラックの上下動に変換される．このラックが下がるこ

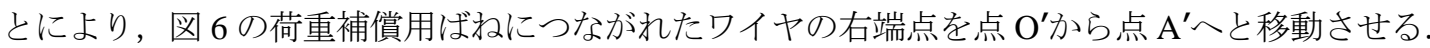

例えば，荷の質量が $M$ であった場合に必要となるギアを選定する. 図 8 に示したそれぞれのギアの半径を $r_{1}$, $r_{2}, r_{3}, r_{4}$ と, ギア間の伝達力を $M g, f_{1}, f_{2}, f_{3}, f$ とすると, 関係式は以下の通りである.

$$
\begin{gathered}
M g=f_{1} \\
r_{1} f_{1}=r_{2} f_{2} \\
r_{3} f_{2}=r_{4} f_{3} \\
f_{3}=f
\end{gathered}
$$

これらの関係から，ラックにかかる力（荷重補償用ばねを伸ばす力） $f$ を求めると，

$$
\begin{aligned}
f & =f_{3}=\frac{r_{3}}{r_{4}} f_{2}=\frac{r_{3}}{r_{4}} \frac{r_{1}}{r_{2}} f_{1} \\
& =\frac{r_{1}}{r_{2}} \frac{r_{3}}{r_{4}} M g
\end{aligned}
$$

となる. 式(10)において， $F_{\text {Spring }}$ の最大值は $\theta=0$ のときなので，ギアの半径 $r_{1} \sim r_{4}$ を次の条件を満たすように設計す ると, 補償量が切替わる.

$$
\begin{gathered}
f>F_{\text {Spring }}: \theta=0 \\
\therefore \frac{r_{1}}{r_{2}} \frac{r_{3}}{r_{4}}>\frac{L}{p_{2}}
\end{gathered}
$$

\section{$3 \cdot 2$ ストッパ機構}

前節で提案した倍力装置によって，荷の荷重を補償するために，ばねを機能させる(伸ばす)ことが可能となっ た.しかし, 図 7 に示寸ように, 作動リンク角度 $\theta$ が $\theta>0^{\circ}$ となると, 荷重補償用ばね端点が点 $\mathrm{D}$ 一スライド してしまう。これは点 $\mathrm{A}^{\prime}, \mathrm{B}^{\prime}, \mathrm{O}^{\prime}$ からなる三角形において， $\theta>0^{\circ}$ のき，線分 $\mathrm{B}^{\prime} \mathrm{O}^{\prime}$ の長さ $p_{2}$ よりも線分 $\mathrm{B}^{\prime} \mathrm{D} の$ 長さ $H$ のほうが短くなるためである，そのため，荷を懸架していない状態においても，荷重補償状態となってし まい，作動リンクが上方に跳衩上がってしまう。この現象を防止するためには，荷重補償を行わない状態におい て, 作動リンク角度によらず荷重補償用ばねの端点がスライドしないように阻止するストッパ機構が必要である. 


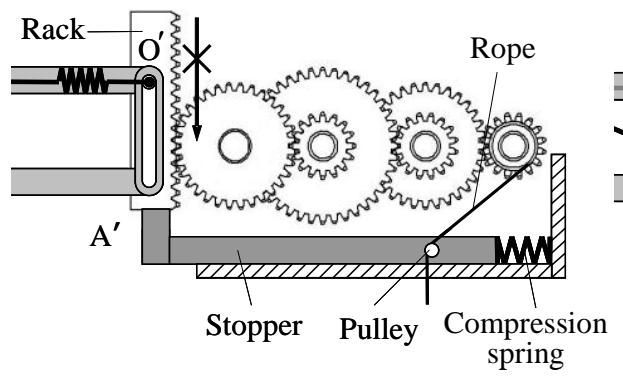

(a) Without luggage

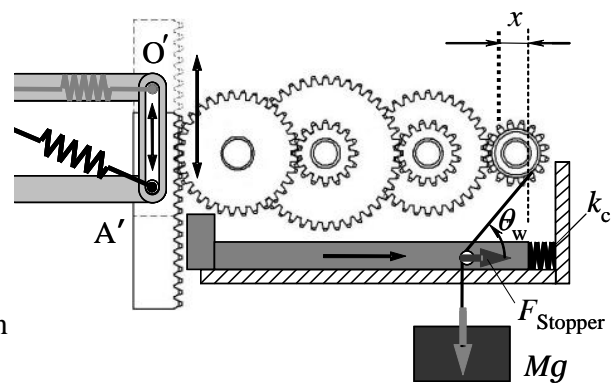

(b) With luggage

Fig. 9 Stopper mechanism

そこで, 図 9 のようなストッパ機構を考案した。機構は, プーリが取り付けられているストッパが倍力装置のラ ックの下部に配置されており，そのプーリには荷を懸架するためのロープが通されている．また，ストッパの右 端には圧縮ばねを取り付けている，荷が懸架されていない状態では，ラックが下方に動かないようにストッパが 機能しており, 作動リンクの姿勢の変化によらず荷重補償用ばねの右端作用点を点 $\mathrm{O}^{\prime}$ に固定することができる(図 9(a)). 荷を懸架した状態では，荷を懸架したフックに連結されているロープが，プーリを右方向に押しやる力を 発生させるため, ストッパが右側に動き，ラックの固定が解除される．このとき，ラックが下方向に動き, 荷重 補償用ばねの右端作用点を点 $\mathrm{O}^{\prime}$ から点 $\mathrm{A}^{\prime}$ ヘとライドさせて, 荷重補償状態となる(図 9(b)). 次に, 荷を取り除 くと, 荷重補償用ばねにつながれたワイヤの右端点が点 $\mathrm{A}^{\prime}$ から点 $\mathrm{O}^{\prime}$ レスライドするので, ラックが上方に移動 して，圧縮ばねの左方向の力により，ストッパが左へ動き，図 9(a)の状態へ戻る. このラックの固定を解除する ために必要なストッパの変位量を $x$, 圧縮ばねのばね定数を $k_{\mathrm{c}}$, 荷重を $M g$, ロープと水平面の角度を $\theta_{\mathrm{w}}$ とする と, 圧縮ばねの弾性力 $F_{\mathrm{c}}$ および荷重によるストッパの右方向の力 $F_{\text {Stopper }}$ は,

$$
\begin{gathered}
F_{\mathrm{c}}=k_{\mathrm{c}} x \\
F_{\text {stopper }}=M g \cos \theta_{\mathrm{w}}
\end{gathered}
$$

となる. ストッパ機構が機能するためには， $F_{\mathrm{C}}<F_{\text {Stopper }}$ とならなければならない. よって，

$$
\begin{aligned}
& k_{\mathrm{c}} x<M g \cos \theta_{\mathrm{w}} \\
\therefore & k_{\mathrm{c}}<\frac{M g \cos \theta_{\mathrm{w}}}{x}
\end{aligned}
$$

を満たすような圧縮ばねを選定することで実現可能である．実際の設計では，ストッパのプーリとロープが巻か れるギアの間隔を変更するなどで， ストッパの変位量 $x$ とロープと水平面の角度を $\theta_{\mathrm{w}}$ を調整できるため, 圧縮 ばねのばね定数を $k_{\mathrm{c}}$ も任意に設定することが可能である.

\section{4. 実機設計・製作}

\section{$4 \cdot 1$ 倍力装置の設定}

図 10 のような機械的荷重補償装置を作成した.この機械的荷重補償装置の荷重補償状態に切替えるために必要 な力 $F_{\text {Spring }}$, 式(10)を用いて求める. 作動リンクは図 10 のように平行リンク機構を用いているので, 荷を懸架 寸るとその力は作動リンクの先端にかかる，そのため，荷の重心位置 $L$ は図 10 の平行リンク長さ $L=189 \mathrm{~mm}$ とな り，また $h_{2}=15 \mathrm{~mm}, p_{2}=45 \mathrm{~mm}$ であるから， 
Table 1 Gear Radius of boost mechanism

Gear Radius [mm]

\begin{tabular}{|c|c|c|c|}
\hline$r_{1}$ & $r_{2}$ & $r_{3}$ & $r_{4}$ \\
\hline 12 & 6 & 15 & 6 \\
\hline
\end{tabular}

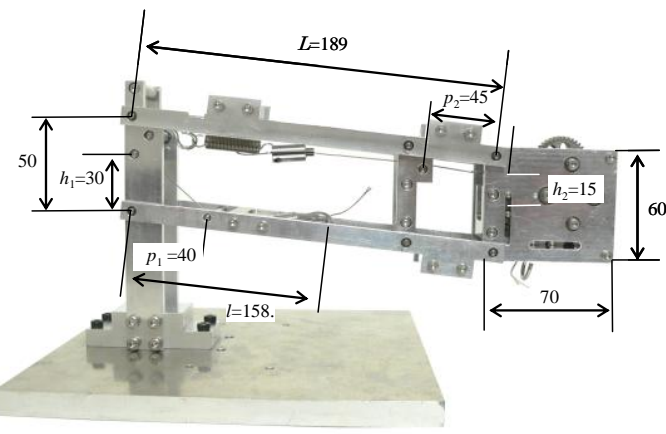

(a) Side view

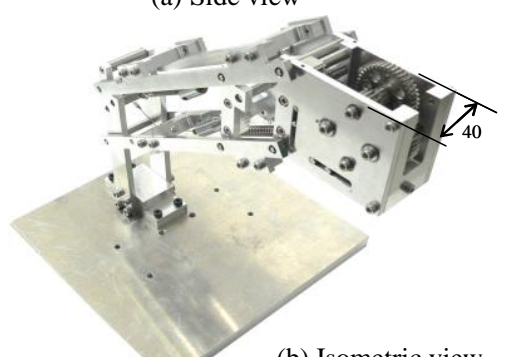

(b) Isometric view

Fig. 10 Overview of WS-MGC
Table 2 Spring constants suspended luggage

\begin{tabular}{|c|c|c|c|c|}
\hline Luggage [g] & 200 & 300 & 500 & 700 \\
\hline$K_{\text {Luggage }}[\mathrm{N} / \mathrm{mm}]$ & 0.546 & 0.819 & 1.36 & 1.91 \\
\hline
\end{tabular}

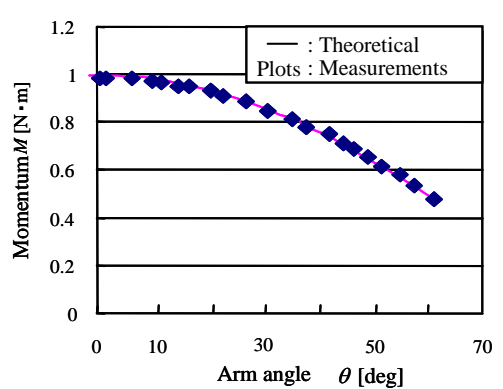

(a) Weight compensation

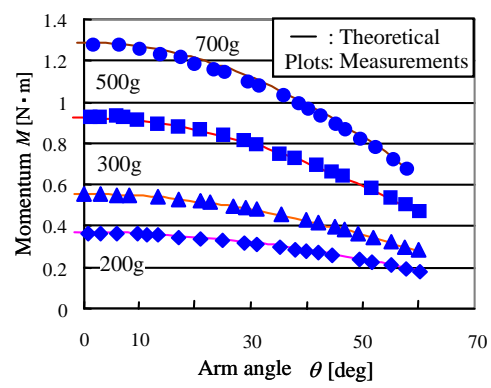

(b) Load compensation

Fig. 11 Measurements of compensation force

$$
\begin{aligned}
F_{\text {Spring }} & =\frac{189(15-45 \sin \theta)}{15 \cdot 45} M g \\
& =4.2(1-3 \sin \theta) M g
\end{aligned}
$$

となり，作動リンク可動域を $0^{\circ} \leqq \theta \leqq 70^{\circ}$ とすると，

$$
F_{\text {Spring }} \leq 4.2 M g
$$

となる.この結果から倍力装置の各ギア径を設定する. 図 8 に示したそれぞれのギアの半径 $r_{1}, r_{2}, r_{3}, r_{4}$ を表 1 のように設定すると，式(12)より倍力装置が生み出す荷重補償用ばねを伸ばす力 $f$ を以下のように設定すると，

$$
f=\frac{r_{1}}{r_{2}} \frac{r_{3}}{r_{4}} M g=5 M g
$$

$F_{\text {Spring }}<f$ となるため, 倍力装置で荷重補償用ばねを伸ばし, 荷重補償状態に切替えることができる.

\section{$4 \cdot 2$ 荷重補償用ばねの選定}

作動リンクは平行リンクであるため, 荷の重心位置は平行リンク長さ $L$ となる. よって荷の質量 $M[\mathrm{~g}]$ に対応す る荷重補償用ばねのばね定数 $K_{\text {Luggage }}[\mathrm{N} / \mathrm{mm}]$ は式(7)より,

$$
\begin{aligned}
K_{\text {Luggage }} & =\frac{M g L}{h_{2} p_{2}}=\frac{M \cdot 10^{-3} \cdot 9.8 \cdot 189}{15 \cdot 45} \\
& =2.74 M \times 10^{-3}
\end{aligned}
$$


となる．㲘架する荷の質量を $200 \mathrm{~g} ， 300 \mathrm{~g} ， 500 \mathrm{~g}, 700 \mathrm{~g}$ と変更して，それぞれに対応する荷重補償用ばねのばね定 数と，既製品から選定したばねのばね定数を表 2 にまとめた.

\section{5. 評価実験}

\section{$5 \cdot 1$ 補償力の測定}

WS-MGC を用いて荷の荷重を補償した場合の操作（上げ下ろし）を行うのに必要な力を測定した. 実験は荷が 懸架されてない状態と, 各荷が懸架されている状態での任意の作動リンク角度時に必要な補償卜ルクと, 各角度 での補償用ばねの伸びをマイクロメータで測定して, 補償トルクに換算した補償トルクを比較した．実験の結果 を図 11 に示寸. 図をみると, 懸架された荷の重さに関係なくどの作動リンク角度でも理論值とほぼ等しい補償卜 ルクが発揮されていることがわかる，そのため，作動リンクと荷重の自重補償が行えていることが確認できた.

\section{$5 \cdot 2$ 補償荷重の切替実験}

切替タイミングの設定角度である作動リンク角度 0 付近で補償量を切替できるか確認した. はじめに, 自重補 償状態から自重および荷重補償状態への切替え $(\mathrm{ON})$ を確認した. 実験方法は, 作動リンクを任意の角度で固定し, フックに荷を懸架して切替が行われるか確認寸る方法である.この確認をリンクが水平 $\left(0^{\circ}\right)$ を基準に上下に $0.5^{\circ}$ 刻みで行い, 初めて切替が成功した角度を切替角度として記録した. 実験の結果は表 3 のようになり, 懸架荷重 が増すにつれて，切替が行われる角度が大きくなる傾向があることが分かる．これは，より大きな荷重を補償す るに従い，機構の各部にそれに比例して大きな摩擦力が働くためであると考えられる．しかしながら，いずれも 微小な誤差であり，作動リンクの動作範囲を制限寸ることもなく，切替に支障はないと考えられる.

次に, 自重および荷重補償状態から自重補償状態への切替え(OFF)を確認した. 実験方法は, 先の方法とは逆 に対応寸る荷がフックに懸架されて荷重補償状態となっている作動リンクを任意の角度で固定し，荷を取り除い たときに切替えが機能する（ラックが上がる）かどうかを確認する方法である.この確認も同様に，作動リンク が水平 $\left(0^{\circ}\right)$ を基準に上下に $0.5^{\circ}$ 刻みで行い，初めて切替が成功した角度を切替角度として記録した.

実験結果は表 3 のようになった，表 3 から分かるように，荷重補償から自重補償に切替える場合も荷が重いほ ど $0^{\circ}$ からズレが大きくなる傾向があることがわかる．しかしながら，荷を賏架する場合と同様に，実用上問題 はなく, 以上より作動リンクが水平 $\left(0^{\circ}\right) に$ 近い範囲で荷の取り付け取り外しだけで補償量の切替えが可能である ことが確認できた. なお，今回の切替動作は，作動リンクが比較的低速で運動した場合を想定している. 作動リ ンクを高速で運動させながら補償荷重を切替る場合には，スライダやストッパなどの直動部に減衰要素を付加す るなどの対策が必要になる.

Table 3 Link angle when switching

\begin{tabular}{|c|c|c|c|c|}
\hline Luggage $[\mathrm{g}]$ & 200 & 300 & 500 & 700 \\
\hline ON angle $\left(^{\circ}\right)$ & 3.0 & 2.5 & 3.0 & 3.5 \\
\hline OFF angle $\left(^{\circ}\right)$ & 0.0 & -0.5 & -0.5 & -1.0 \\
\hline
\end{tabular}




\section{6. 結 語}

本研究では，機械的自重補償装置に倍力装置を利用した補償量切替機構を追加した機械的荷重補償装置を考案 した．装置を製作し，実験と理論との比較によって，その効果を確認した．得られた成果は以下の通りである.

1. 自重補償用ばねと荷重補償用ばねを別々に設け，荷重補償用ばねを変更することで容易に補償できる荷重を 設定できることを示した.

2. ギアを用いた倍力装置とラックを用いた切替え装置によって, 荷を䀣架するだけで補償力を切替えられるこ とを示した。

3. 機械的荷重補償装置(WS-MGC)を用いて荷を操作する際も自重補償が可能であることを確認した.

\section{文献}

(1) Ulrich, N., Kumar, V., Passive Mechanical Gravity Compensation for Robot Manipulators, Proceedings IEEE International Conference on Robotics and Automation, (1991-4), pp.1536-1541.

(2) Hirose, S., Development of a Lightweight Torque Limiting M-Drive Actuator for Hyper-Redundant Manipulator Float Arm, Proceedings IEEE International Robotics and Automation,ICRA 1999, (1999), pp.2831-2836.

(3) 森田寿郎, 塩澤裕樹, 中井英俊, 栗原史好, 菅野重樹, 高運動性能マニピュレータのための機械的 3 次元自重補償 機構の開発ロボティクス・メカトロニクス講演会講演概要集, Vol. 2002, No. Pt.4, (2002), pp. 2P1.H03(1)-2P1.H03(2).

(4) Hirose, S., Ishii, T., Haishi, A., Float Arm V: Hyper-Redundant Manipulator with Wire-Driven Weight Compensation Mechanism, Proceedings IEEE International Robotics and Automation, ICRA 2003 in Taiwan, (2003), pp.368-373.

(5) Morita, T., A novel mechanism design for gravity compensation in three dimensional space, Proc. 2003 IEEE/ASME International Conference on Advanced Intelligent Mechatoronics, Vol.1, (2003), pp.163-168.

(6) 広瀬茂男, 大西正志, 河上篤史, Claudio Semini, 自重補償多関節型 Float Arm の研究:シングルプーリを用いた Float Arm VI の開発”, 第23 回日本ロボット学会学術講演, Vol.23, (2005), pp.3A17.

(7) 森田寿郎, 自重補償機構の設計原理と動作支援技術への応用, バイオメカニズム学会誌, Vol. 30, No.4, (2006), pp.200-204.

(8) 梅田幹雄, スイカ収穫ロボットこうのとり"の開発, 日本機械学会ロボティスク・メカトロニクス講演会論文集, Vol. A, (1997), pp. 41-42.

（9）金丸恵輔，森田寿郎，精密位置決めを可能とする機械インピーダンス特性を備えた鼻内手術用内視鏡保持装置，日 本機械学會論文集-C 編, Vol. 73, No. 730 (2007), pp. 1769-1776.

(10) Shimoi, Y., Kanemaru, K, Fujishima, K., Tomita, k., Iwasaki, A. and Morita, T., Operability Assesment of Indoor Dsimantlement Assistance Machine, The 23rd International Symposium on Automation and Robotics in Construction 2006, pp.822-827.

\section{A. 付録 MGC}

\section{A 1 実施例}

MGC を利用した実施例は，MGC が作動リンクの補償力を途中で変化することができないため，肩装具 ${ }^{(7)}$, 鼻

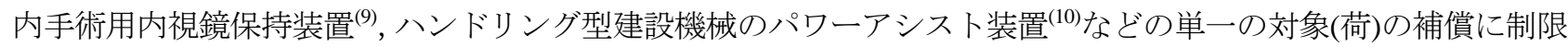
されている.

\section{A 2 補償原理}

MGC の原理モデルを図 A に示す．支柱と作動リンクが接続されている回転軸を点 $\mathrm{O}$ ，作動リンクの先端側の 端点を点 $\mathrm{O}^{\prime}$ とし, 点 $\mathrm{O}$ から支柱に沿って $h$ の距離の点を点 $\mathrm{A}$, 点 $\mathrm{O}$ から作動リンクに沿って $p$ の距離の点を $\mathrm{B}$

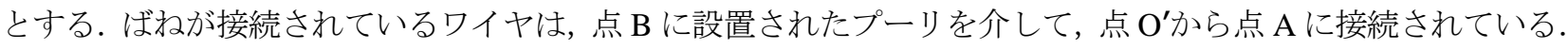


ここで，リンクにばねを設置する場合は，ばねの自然長は点 $\mathrm{B}$ から点 $\mathrm{O}$ 間内に収まるように決定する。ばね定数 は $k$ とし, ばねの自然長からの伸び量が $l_{\mathrm{s}}$ と等しくなるように調整する. 作動リンク重心は点 $\mathrm{O}$ から $l$ の距離と し，作動リンク質量を $m$ とする．点 $\mathrm{O}$ まわりに発生するばねカトルク $\tau_{\mathrm{L}}$ は,

$$
\tau_{\mathrm{L}}=k l_{\mathrm{s}} h \sin \varphi
$$

となる、また，図 A の幾何条件から

$$
l_{\mathrm{s}} \sin \varphi=p \cos \theta
$$

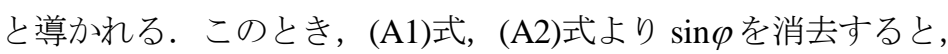

$$
\tau_{\mathrm{L}}=k p h \cos \theta
$$

となる. 一方で，重力加速度を $g$ とするとアームの自重トルク $\tau_{\mathrm{O}}$ は

$$
\tau_{\mathrm{O}}=m g l \cos \theta
$$

となる.ここで，ばね定数 $k$ を

$$
k=\frac{m g l}{p h}
$$

とすると, $\mathrm{O}$ 点まわりのトルク $\tau_{\text {grav }}$ は

$$
\begin{aligned}
\tau_{\text {grav }} & =\tau_{\mathrm{L}}-\tau_{\mathrm{O}} \\
& =k h p \cos \theta-m g l \cos \theta \\
& =0
\end{aligned}
$$

となり，作動リンク角度によらず自重補償が可能となる.

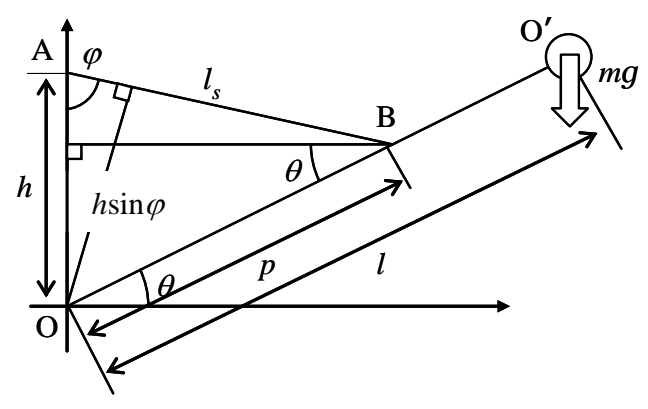

Fig. A Configuration of MGC 